\title{
REPRESENTATION OF NATURAL AND SPATIAL CONCEPTS IN PERCY BYSSHE SHELLEY'S POETRY
}

\author{
Nataliia Romanyshyn
}

\author{
Lviv Polytechnic National University, \\ 12, Stepana Bandery Str., Lviv, Ukraine, 79000 \\ nataliya.romanyshyn@gmail.com
}

\begin{abstract}
The article reveals the peculiarities of imagery representation of spatial and natural concepts in poetic discourse of Percy Bysshe Shelley through the analysis of author's individual stylistic preferences, manner and regularities of imagery patterns, motives, and compositional lines development. It defines the systemic ways and principles of symbolic and associative parallelism development between natural elements and versatile aspects of existential notions and phenomena. The achieved results allow establishing the most conspicuous features of author's poetics, typical metaphoric models, in which natural elements and phenomena constitute source and target domains of metaphorization, and the spectrum of their symbolic meanings. Reconstruction of author's artistic conceptual model is based on the assumption about the essential feature of poetic language, its imagery-symbolic and lexical semantic potential as the main means of literary concepts verbalization, their cognitive, aesthetic and emotional-expressive embodiment.
\end{abstract}

Key words: poetry, Romanticism, Percy Bysshe Shelley, literary concept, literary discourse.

Introduction. Modern approach to the study of poetry from cognitive, cultural and semiotic perspectives manifests a deep shift in the treatment of the category of text - from a purely lingual fact created according to a set of constructive rules to a complex sense generating entity [9]. Any literary text represents both author's worldview and the system of national imagery conventions embodied in a culture-specific picture of the world that constitute the basis of artistic communication. Thus, informative, conceptual and verbal dimensions of a literary text are a synergy of author's subjective, individual and collective, national cognition. Literary text, therefore, develops as a link of literary-aesthetic communication which results in the formation of the holistic idea about author's conceptual system as integral unity of logical, notional, evaluative and ethical manifestations in their inseparable connection to national culture and mentality as well as in the context of dominant philosophical theories, and impact of conventional artistic patterns.

This paper aims at revealing the peculiarities of imagery representation of concepts SPACE and NATURE in poetic discourse of Percy Bysshe Shelley through the analysis of author's individual stylistic preferences, types and regularities of imagery patterns, motives, and compositional lines development. The study of individual poetic system is based on the sophisticated analysis of different manifestations of author's intellectual creative activity to provide an insight into the poet's conceptual picture of the world, and his system of values and principles.

(C) Romanyshyn N., 2019 
Theoretical background. Shelley's poetic heritage has been addressed in a great number of researches. Scholars focus on its versatile aspects, among which the problems of Shelley's poetic reinterpretations and reconsiderations of different philosophic, social, political, and aesthetic doctrines, reception of theological and scientific ideas concerning the universal principles and fundamentals of human existence, and comprehension of physical natural world dominate $[1 ; 3 ; 8 ; 12]$. Scholars vigorously discuss Shelley's special place in the English literature and his almost mythological status informed by the poet's striving to explore the quintessence of poetry. According to Michael O'Neill, recent literary criticism of Shelley's poetry has affirmed "Shelley's many-sidedness and the many dimensions of his achievements as well as the reception to different approaches and possibilities" [7:11] which opens diverse analytical perspectives $[2 ; 4 ; 5 ; 6]$. However the exaggerated attention to philosophical and social contexts and ideological and religious vectors in contemporary researches on Shelley overshadow the issues of lingual and aesthetic peculiarities of his works as well as the consideration of poetic means for depicting a human being and the scope of his existential problems - life, soul, natural and civilized environment - which makes it possible to reveal culture-specific features of poetry and the dynamics of poetic forms within the boundaries of a national type of Romanticism.

Methods. The theoretical background of the presented research is based on the works of native and foreign scholars in the field of lingual poetics (V. Vinigradov, R. Jacobson, O. Potebnia), cognitive poetics (M. Turner, R. Tsur, L. Talmy, A. Palmer, R. W. Langacker, G. Lakoff, Z. Kövecses, M. Freeman, G. Fauconnier, L. Belekhova, O. Vorobyova), stylistics (O. Malenko, O. Matsko), and literary criticism (U. Eco, O'Neill, R. G. Woodman, D. Nalyvayko, S. Pavlychko, L. Nieupokoyeva), which are characterized by a synthetic comprehension of text, in particular literary/poetic text, as a polyaspectual, polymorphic, multilevel verbal entity, which is both a completed result of individual poetic and aesthetic creativity and a product of artistic communication, open for the unlimited number of interpretations, between the author and the reader. It also applies the theories in the fields of linguacultural and linguaconceptual studies (Y. Stepanov, S. Vorcatchov, V. Maslova, E. Vereshchagin, $\mathrm{V}$. Kostomarov) that determine the anthropocentric approach to the language as a product of individual and collective consciousness and a cognitive instrument of representing the national picture of the world.

In the paper we use the term of literary concept which we define as linguacognitive representation of poetic artistic world on a general cultural plane and on the plane of expressing the uniqueness of creative personality and, simultaneously, the result of penetration into the semantic space of literary text and its cognitive processing and aesthetic comprehension by the recipient, represented in the concentrated form. Thus, literary concept is a bilateral dialogic lingual, cognitive and aesthetic unity emerging in the process of constant dialogue between the author and the reader that occurs in certain artistic forms within a certain culture and time. In this paper we, following the thematic principle of concepts classification, acknowledged in modern linguistics, concentrate on those literary concepts in Shelley's poetic discourse that are defined according to their semantic correlation with thematic groups of space and nature.

Penetration into the processes of literary semantics rests upon the comprehension of the unity between form and content, or meaning and sense of a poetic text. The fundamental quality 
of artistic merit lies in the correlation of internal and external planes of the text as a possibility of embodying similar content in different verbal shapes and vice versa. Consequently, the analysis of poetic text's semantics means the reconstruction of factors that create its sense $[10$, p. $97 ; 13 ; 14$, p. 43-44, 273-274, 290-291]. The reconstruction of the author's artistic conceptual model is based on the assumption about the essential feature of poetic language, its imagery-symbolic and lexical semantic potential as the main means of literary concepts verbalization, their cognitive, aesthetic and emotional-expressive embodiment.

In this research we apply the methods of metadescription developed by Y. S. Stepanov several decades ago as an efficient tool of "working out" the poetic sense from the mass of typical poetic images - from a single poetic fact or image (selected by a researcher as a starting point of analysis) to a set of images on a higher level, metaimages, macroimages, key textual theme, and a dominant idea of author's world outlook [14, c. 289-292]. This methodology is highly productive and is applied in modern studies of artistic conceptualization, enriched by theoretical ideas of different humanitarian disciplines aimed at revealing the uniqueness of collective and individual literary consciousness.

Proceeding from the understanding of a multifaceted nature of text semantics, the analysis of text conceptual structure as a stable invariant, or a pivoting point of sense-generating processes, rests upon the following: the consideration of style and genre characteristics of the text in order to delineate possible interpretations on logical, social and historic planes; extralingual factors of text creation; possible psychological aspects of creative activity. The analytical procedures include the study of lingual stylistic, cognitive, functional, and semiotic features of the text by means of stylistic, semantic, and semiotic analyses. The consideration of the role of pragmatic factors in verbalization of axiological aspects of poetic concepts, in particular, social and contextual determination of verbal images and the development of their meaning within social semiotic systems requires the application of pragmatic, contextual and discourse analyses. In order to reveal the aesthetic qualities of the poetic text it is essential to resort to the analysis of stylistic resources and compositional and narrative patterns in their correlation with the stages of national literary cognition evolution.

The above listed parameters of the research involve the symbiosis of different methodological models that address the problem of textual meaning not as a static internal feature but as a dynamic result of literary discursive practices and provide an unlimited range of analytical activities, choice of research vectors, and flexibility of research systems stages and procedures.

Results and Discussion. A specific character of Shelley's interpretation of the environment, both physical and social, lies in the transposition of general romantic correlation model "nature - human soul" into "nature - human will, cognition, mind" one, with the attention to transitory states of nature and human psyche that exceed the boundaries of the visible and comprehensible. Shelley's poetic space is a space of cosmic freedom, which encompasses the motion of celestial bodies, wind, storms, and unrestricted flood of energies. Shelley's figurative language consists in the arbitrariness of phantasmagoria, endless surge of metaphors, similes and epithets, often contradicting and highly unpredictable, organized without any logical restriction. It is as if split between two poles - ideal and formal complexity and irresistible striving for harmony, clarity, transparency, which add elitism and intellectual 
beauty to his poetic discourse. These shifts in artistic cognition, intellectualization of poetic expression, innovation of poetic word and its refinement represent an obvious tendency towards modernization of poetic thesaurus. They manifest themselves in the actualization of spatial concepts HEAVEN, LIGHT, WIND, SPACE, INFINITY, MOTION as extremely generalized notions close to philosophic abstractions. In their representation the author gives preference to the motives of fantastic, "tempestuous" landscapes, to the motive of communication between the rational essence of the nature and thinking "ego".

National toponymy, flora and fauna, are sporadically and superficially represented in Shelley's poetry. National landscape seldom constitutes a self-contained poetic motive, with the exception of the poem The Isle which, according to the mode of poetic elements organization and development, can be related to the notion of "ideal landscape" [15, p. 126] displaying all corresponding attributes - delicate flowers, richness of colours, soft wind, sunshine, the vastness of perspective, completeness, and harmony.

Most plots of Shelley's lyrical poems include idealized landscapes to highlight the contrast between the beauty of nature and sufferings of human soul, earthly troubles and pain, realization of the impending death, or attenuation of love: Come, be happy!-lie thee down/On the fresh grass newly mown,/Where the Grasshopper doth sing/Merrily-one joyous thing/In a world of sorrowing! (Invocation to Misery). Or, on the contrary, the nature may oppose positive human feelings by darkness, coldness and distortions. The protagonist and the environment are as if involved into a secret struggle that makes human feelings and emotions stronger, more perceptible, and insuperable. Semantic structure of such poetic microcontexts develops due to the words-symbols, whose semantic potential is practically unrestricted (names of colours, words of sense perception, and words with the meaning of motion, change, state or static character), organized on the basis of antithesis. The poet deepens and modifies the existing romantic tradition of text creation in which the semantic syncretism of natural and spatial images-symbols determines corresponding psychological and intentional direction of their interpretations. This textual semantics development is aimed at "artistic representations of persona's existential reflections whose lonely and tired soul strives for, yet seldom finds, an internal and external concord with the world of nature" [11, p. 300], as in the poems Despair and Remorse.

The poet seldom resorts to the practice of "socialization of landscape" as a conventional way to make contrast between idyll of nature and social injustice (the poem Summer and Winter). In most poems, where the national landscape - either generalized or specific natural region description - serves as an introduction to the development of a lyrical plot, Shelley exceeds the bounds of artistic device of psychological substantiation of nature and space, breaks the principle of equivalence between landscape and feelings or reflections, and endows the landscape with new poetic functions. These individual devices include the transference of ideal landscape to the plane of a dream, fantasy, myth (poems The Aziola, Arethusa, The Woodman And The Nightingale, Hymn Of Apollo, Hymn Of Pan), transformation of landscape into the "portal" through which it is possible to communicate between the real and unreal, supernatural worlds.

In Shelley's poetic discourse, natural images represent the comprehension of metaphysical foundations of existence, pure abstract natural elements devoid of any concrete relation to 
a defined area. Forms of national landscape representation are overshadowed by primordial natural powers, idealized in their manifestations, as a gravitation point that attracts doubting human thought and tormented soul "on the false earth's inconstancy, amid the varied multitude" through space and time. This extreme abstractness and timelessness in artistic representation of nature determines the ways of natural phenomena poetic embodiment and symbolization. Natural elements and phenomena become the symbols of universal notions - liberty, life, death, good, evil, creativity, cognition, love, beauty. Among different natural elements the preference is given to the images of air and fire that represent spatial poetic concepts WIND, CLOUD, SUN, MOON, STARS, HEAVEN, SPACE (poems The Cloud, Ode To The Western Wind).

In Shelley's poetry, the imagery conceptualization of the cloud is endowed with a specific evaluative ambivalence, embodying both positive, life giving and negative, destructive notions, which on the textual level are reflected in a high density of anthropomorphic images and mythological allusions aligned in a complex of metaphors - either trite, traditional, revived by the novelty of poetic expressions or genuine, loaded with an outstanding aesthetic importance due to direction of thought towards unexpected, latent feature of source and target domains: "Cloud - the source of moisture - life" (I bring fresh showers for the thirsting flowers - From my wings are shaken the dews that waken The sweet buds every one). "Cloud - abode of thunder and lightning" $\rightarrow$ " lightning - pilot" $\rightarrow$ "cloud - celestial ship" (Sublime on the towers of my skiey bowers, Lightning, my pilot, sits; Over earth and ocean, with gentle motion, This pilot is guiding me). "Cloud - celestial cover, roof" (my tent's thin roof; my windbuilt tent; Sunbeam-proof, I hang like a roof) "Cloud - banner" (the whirlwinds my banner unfurl). "Cloud - a horse ridden by the Sun" (The sanguine Sunrise, with his meteor eyes,/ And his burning plumes outspread, Leaps on the back of my sailing rack, When the morning star shines dead). The metaphor "cloud - bird" realizes occasional association (bird $\rightarrow$ nest) rather than traditional (bird $\rightarrow$ flight) one: With wings folded I rest, on mine aery nest,/As still as a brooding dove. There are cases of so called "interiorization" of natural phenomenon where the latter is used for metaphorization of human intellectual abilities - the metaphor "cloud - thought": When silvery clouds float through the wildered brain.

Clouds that create oppressive, dangerous, mysterious atmosphere symbolize sorrow, grief, misfortune, fear - with emotional and expressive saturation of context by complex allegories and hyperboles (AWAY! the moor is dark beneath the moon,/ Rapid clouds have drunk the last pale beam of even (Remorse) From a single cloud the lightening flashes,/ Whilst a thousand isles are illumined around (Liberty) supported by expressive emotional epithets (Rough wind, that moanest loud / Grief too sad for song;/Wild wind, when sullen cloud/Knells all the night long; Driven like a homeless cloud; If I were a swift cloud).

The other natural power engaged in spatial imagery is the wind. In the development of "wind" images Shelley preserves a general romantic tradition of representing human existence through nature; however, his poetic associations are more intellectualized and sophisticated. Natural phenomena represent intimate, personal, social and spiritual concepts related to a human being as "activators" of social-historic or intellectual changes. The content of the literary image is enriched due to the activation of lexical-semantic and associative aspects 
of contextual elements as well as the reinforcement of mythological subject or parabolic schemes. For example, the introduction of the well-known Shelley's poem Ode To The West Wind contains the actional scheme "wind that carries and sows the seeds", its finishing part - the actional scheme "wind that penetrates human body, soul and mind" correspondingly, which create associative connections between the wind and intellectual power (Be thou, Spirit fierce,/My spirit! Be thou me, impetuous one!/Drive my dead thoughts over the universe/Like withered leaves to quicken a new birth!). The activation of imagery-associative lines based on conventional mythological content "lyre singing to the wind - poetic creativity - prophecy" makes the wind a symbol of poetry and art: Make me thy lyre.../And, by the incantation of this verse,/Scatter, as from an unextinguished hearth/Ashes and sparks, my words among mankind!/Be through my lips to unawakened earth/The trumpet of a prophecy!

An important place in Shelley's poetic thesaurus belongs to cosmic images - the Sun, the Moon, the sky, stars, light and colours, fire, rays, irradiation, whose lingual and aesthetic development manifests the dynamics of expressive means of the national language, actualization of aesthetic and cognitive functions of poetic language ranging from typical, stereotyped, adopted by the previous literary experience imaginative schemes (smile of the sun, sunny bird, wandering moon: When will the sun smile on the bloodless field; Wandering companionless) to specific individual discoveries projected by artistic intentionality, author's system of values, priorities of his worldview. For example, he sky is both - the idea of universality, infinity and roof of the earth, its cover, dome, protection (The pavilion of Heaven; Palace-roof of cloudless nights; Presence-chamber, temple, home,Ever-canopying dome, Of acts and ages yet to come!); the sky as eternity, blessing, or paradise is traditionally opposed to the hell. The sky is the source of goodness, freedom and at the same time the aim of achieving freedom, the center of purity, innocence, love, the power directed to the earth in order to liberate it from the sin, evil and hatred. Visual imagery of the sky and celestial objects is created on the basis of colour, fire and light symbolization which fill the context with aesthetics and desirable emotional effect - elevation and solemnity (red, blue, gold, silver, white, nacre, burning, shining, irradiation); or, on the contrary, oppressiveness, dullness, depression (black, pale colours, indefinite colouring and shades, crimson): Heaven's ebon vault,/Studded with stars unutterably bright; The sanguine Sunrise, with his meteor eyes,/And his burning plumes outspread; And pallid Evening twines its beaming hair/In duskier braids around the languid eyes of Day.

Motion as an integral aspect of space, the characteristic of life, matter and human being, and of the dynamics of material, spiritual, psychological and intellectual manifestations is one of the most elaborated categories in Shelley's poetics, especially when we consider its role in the representation of natural and spatial concepts - absence of defined territorial dominance, the beginning and end, and low frequency of static landscape subjects. Poetic actualization of the category of motion manifests itself in typical tropes, mainly metaphors based on the metaphoric models - celestial body/object - traveller/bird (Art thou pale for weariness/Of climbing heaven and gazing on the earth; Moon, thou pale and gray/ Pilgrim of Heaven's homeless way); anthropomorphic and zoomorphic metaphors created on the ground of verbal semantics, symbolism and associativity, related to the direction and character of the motion (the lingering beam of day; Cloud upon cloud, in dark and 
deepening mass,/Roll o'er the blackened waters; Tempest unfolds its pinion o'er the gloom/ That shrouds the boiling surge).

Shelley's poetic imagination is able to reach cosmic energies and motion of cosmic objects endowed with specific characteristics - colours, purpose, and sound: (Above, below, around,/The circling systems formed/A wilderness of harmony;/Each with undeviating aim,/In eloquent silence, through the depths of space/Pursued its wondrous way; the Hall of Spells; that unearthly dwelling; The light and crimson mists,/Floating to strains of thrilling melody).

Shelley frequently resorted to the artistic device of depicting the flight of the soul into extraterrestrial spheres as a way to comprehend, in poetic forms, the essence of human existence and to reveal the highest reality of spiritual worlds is harmoniously interconnected with aesthetic representation of real earthly landscapes: There, far as the remotest line/That bounds imagination's flight, Countless and unending orbs/In mazy motion intermingled; sphere of earthliness;/Where silence undisturbed might watch alone-/So cold, so bright, so still. This interconnection constitutes a specific view as if simultaneously from inside and outside, of the beauty and perfection of the Universe. This poetic perspective considerably modifies a semantic scope of the literary concept SKIES/HEAVENS which means both the atmosphere of the earth and the space, where the earth as an object of poetic depiction is displayed in its versatile aspects.

Mutability, beauty, unattainability and, at the same time, intimacy in the comprehension of celestial bodies, the light that they irradiate, their reflection in the space and play of shadows make them "programmed" to create symbolism and complex ideological values. Highly productive typical spatial images based on the corresponding concepts as source or target domains are used to express different existential notions, for example, the Moon represents incomprehensibility of death: HOW wonderful is Death,/Death, and his brother Sleep!/One, pale as yonder waning moon/With lips of lurid blue; purity, calmness: the moon's pure beam; fluctuation, instability or, on the contrary, stability, a pivoting point of life: We are as clouds that veil the midnight moon; / How restlessly they speed, and gleam, and quiver, / Streaking the darkness radiantly! Stars represent renovation: Those who have struggled, and with resolute will/Vanquished earth's pride and meanness, burst the chains, / The icy chains of custom, and have shone/The day-stars of their age; freedom: Can the daystar dawn of love,/Where the flag of war unfurled / Floats with crimson stain above / The fabric of a ruined world? A meteor represents the flash of life: Is the flame of life so fickle and wan/That flits round our steps till their strength is gone. The earth as a planet represents fragility, vulnerability: There was a little light/That twinkled in the misty distance; fluidity, predestination, fatality: The last of the flock of the starry fold; woman, deity endowed with sensitivity: Mother Earth?;Thou wert warming thy fingers old/O'er the embers covered and cold/Of that most fiery spirit.

The universe of the nature not only irradiates colours and light or is shrouded by shadows; it is filled with sounds, whose acoustic characteristics in their poetic realization encompass low registers and serve as an accompaniment of so-called "tempestuous" landscapes: December is howling; the wild waves are rolling; the thunder peals rattle Fierce roars the midnight storm; The whirlwind is rolling,/The thunder is tolling,/The forest is swinging,/ The minster bells ringing; Ghosts of the dead! have I not heard your yelling/Rise on the night-rolling breath of the blast; And all around,/With a chilling sound,/From caves of ice 
and fields of snow/The breath of night like death did flow/Beneath the sinking moon; a thrilling sound,/Half sense half thought, among the darkness stirs. This manifold acoustic accompaniment pertains to the reflections over the sense of life and human existence, fate, secrets of life and death and reveals the hidden senses for a sensitive heart: Ghosts of the dead! have I not heard your yelling/Rise on the night-rolling breath of the blast; Silence and Twilight, unbeloved of men,/Creep hand in hand from yon obscurest glen./They breathe their spells towards the departing day,/Encompassing the earth, air, stars, and sea; Light, sound, and motion, own the potent sway,/Responding to the charm with its own myste (A Summer Evening Churchyard, Lechlade, Gloucestershire).

The acoustic aspect of the spatial images in Shelley's poetic discourse is one of the multifold forms of the anthropomorphism of natural elements as a leading principle of cognitive and lingual-aesthetic representation of nature in Romanticism. The nature is not only able to produce sounds but also to communicate meaning and to commence a dialogue responding to human needs. Numerous poetic contexts include expressions with different communicative meanings, addressed to nature - dialogues between a human being and nature (poems Lines Written On Hearing The News Of The Death Of Napoleon, On The Dark Height Of Jura та The World's Wanderers).

Shelley's spatial-landscape imagery system in poetic works that belong to different genres - landscape, intimate, civil poetry, epic poems - is an organic embodiment of the unity of philosophical thought, aesthetics of emotions and richness of sense perceptions enabling to encompass the motion and interaction of natural and social elements and powers.

Using his poetic word, Shelley responds to and polemicizes with his brothers of the quill, "charging" traditional, frequently reconstituted natural and spatial romantic images with new conceptual content. Applying the traditional romantic literary device of endowing the natural universe with psychological features, the poet strives to intellectualize the powers of nature, displaying them not only as the cause of feelings and the source of lyrical reflections but as a thinking substance, an impetus of cognitive and creative activity of a thinking subject. Human mind is, therefore, the center of energies interaction, able to cognize, to renovate, to discover the new, the secret, tending to creative life asserting activity, whereas the nature itself is a thinking creative energy, able to saturate human cognition: The everlasting universe of things/Flows through the mind, and rolls its rapid waves... The source of human thought its tribute brings/Of waters - with a sound but half its own,... Dizzy Ravine! and when I gaze on thee/I seem as in a trance sublime and strange/To muse on my own separate fantasy,/My own, my human mind, which passively/Now renders and receives fast influencings,/Holding an unremitting interchange/ With the clear universe of things around ... (Mont Blanc: Lines Written In The Vale Of Chamouni).

The cited poem Mont Blanc: Lines Written In The Vale Of Chamouni confirms the above mentioned tendency towards the transformation of traditional imagery system, its complexification, and revivification of polyphonic semantic streams. The imagery network of this poem is based on the development of the following semantic and associative shades: "river - irrepressible flow of energy - extremely abstract mystic power - inspiration"; "the nature - container of all controlling force - abode of power and thought"; "wind - allembracing, universal mind - insurgent of cognitive vigour - an instrument of extracting 
and scanning the sacred senses in natural manifestations (sounds and fragrances), reviving creative potential".

Specific semantic and associative-symbolic transformations of dominant romantic images are reflected in Shelley's addressing the image of skylark. Whoever of the world's romantic poets eulogizes this little bird, they choose as a key poetic meaning the ethical and aesthetic ideals, harmony and beauty, and poetic inspiration. Following in his poetry the traditional imagery associative line "skylark - symbol of poetry and poesy," Shelley enriches the content of the image by new meanings: "skylark - center, point of intersection of natural powers of fire, earth, air - celestial azure" (From the earth thou springest Like a cloud of fire). The skylark is the source of infinite joy (Like an unbodied joy whose race is just begun) and the life-giving energy which is nourished by the beauty of nature and invigorates the creative potential of a human being itself. Compared to the sacred spirit of nature, the skylark is able to rise over the dark side of mundane life (Shadow of annoyance; love's sad satiety; scorn/ Hate, and pride, and fear), representing the human ideal defined as a mission to achieve natural harmony and sociable justice as an unavoidable and irrefragable stage of human history evolution.

Conclusions. The uniqueness of Shelley's poetic cognition, analyzed in this article from the perspective of the poet's approach to actualization of natural and spatial literary concepts, consists in his desire to encompass and reveal, through their symbolism, different notions and phenomena of individual and social existence. Nature in Shelley's poetic discourse is represented in its most abstract and universal forms.

A leading place among versatile literary and aesthetic devices of Shelley's poetics belongs to allegories and complex compositional metaphors developed on the basis of universal symbolic and associative parallels between nature and human being, nature and society. While modeling corresponding literary concepts, these devices allow revealing fundamental universal existential principles, complexity and interaction between human psyche, soul, creativity and cognition. Timelessness and lack of specific historic and locational definiteness in the process of poetic concepts modeling allow the author to recreate the universal idea of struggle between the good and evil.

The complex semantics of natural images serves as a source of poetic symbolization of interrelation between a human being and environment. Natural elements in Shelley's poetry are endowed with intellect, vigour of creativity, joy and poetic polyphony which influence the "plasticity" of poetic language organization.

The greatest achievement of Shelley's poetry consists in overcoming the characteristic trend of Romantic thinking, that of "the world sorrow and disillusion", its dominative motive of "escape to the nature", "reflexivity and psychologism" of the romantic landscape poetization by disclosing intellectual and cognitive potential of nature. Consequently, the optimistic prophetic essence of Shelley's poetry lies in his belief in absolute freedom and harmony reigning in the nature, which must serve as an example of harmony, freedom and justice in the ideal future state of the humankind as its primordial fundamentals.

In this paper, an attempt was made to perform a complex analysis of the representation of natural and spatial concepts in Shelley's poetry through the system of poetic images and to define the systemic ways and principles of symbolic and associative parallelism development 
between natural elements and versatile aspects of existential notions and phenomena. However, due to the unfathomable depth of Shelley's poetry, the questions about semantic and symbolic potential of natural and spatial images has not been and could not have been completely exhausted. The establishment of their role in the poet's and national conceptual picture of the world is the next topical issue of further investigations.

\section{REFERENCES}

1. Baker J. E. Shelley's Platonic answer to a platonic attack on poetry / J. E. Baker. - [Ed. by J. E. Baker]. - Iowa Univ. press, 1965. - 172 p.

2. Barcus J. E. Percy Bysshe Shelley: The Critical Heritage / J. E. Barcus. - Routledge, 1995. $-52 \mathrm{p}$.

3. Bloom H. Shelley's mythmaking / H. Bloom. - Ithaca-N.Y., 1969. - 278 p.

4. Duffy C. Shelley and the Revolutionary Sublime / C. Duffy. - Cambridge : Cambridge University Press, 2005. - $260 \mathrm{p}$.

5. Howe A. Shelley and Philosophy: On a Future State, Speculations on Metaphysics and Morals, On Life / A. Howe // The Oxford Handbook on Percy Bisshe Shelley [Ed. M. O'Neill, A. Howe]. - Oxford : Oxford University Press, 2013. - P. 101- 117.

6. Hugh R. Shelley and the chaos of history: a new politics of poetry / R. Hugh. - University Park : Pennsylvania State Univ., 1997. - 530 p.

7. O’Neill M. Introduction / M. O’Neill // The Oxford Handbook on Percy Bisshe Shelley [Ed. M. O’Neill, A. Howe]. - Oxford : Oxford University Press, 2013. - P.-115.

8. Woodman R. G. The apocalyptic vision in the poetry of Shelley / R. G. Woodman. - Toronto : Univ. of Toronto, 1966. -209 p.

9. Воробьёва О. П. Образ текста в филологических студиях: когнитивно-семиотический аспект / О. П. Воробьёва // Проблемы представления (репрезентации) знаний в языке. Типы и форматы знания: Сб. науч. тр. / РАН, Ин-т языкознания; МОН РФ; ТГУ им.Г.Р.Державина:[подред.КубряковойЕ.С.,ПоздняковойЕ.М.идр.].-Москва-Калуга: ИП Кошелев (Изд-во “Эйдос”), 2007. - С. 278-286.

10. Кагановська О. М. Текстові концепти художньої прози (на матеріалі французької романістики середини ХХ сторіччя) / О. М. Кагановська. - К. : Вид. центр КНЛУ, 2002. -292 c.

11. Маленко О. Лінгво-естетична інтерпретація буття в українській поетичній мовотворчості (від фольклору до постмодерну) / О. Маленко. - Харків : ХНПУ, 2010. - 488 с.

12. Неупокоева И. Г. Революционный романтизм Шелли / И. Г. Неупокоева. - М. : Государственное издательство художественной литературы, $1959-471 \mathrm{c.}$

13. Рикер П. Конфликт интерпретаций. (Очерки о герменевтике) / П. Рикер - М. : Прогресс, 1995. - 367 с.

14. Степанов Ю. С. Французская стилистика (в сравнении с русской)/ Ю. С. Степанов. М. : Эдиториал УРСС, 2003. - 359 с.

15. Эпштейн М. Н. Природа, мир, тайник вселенной. Система пейзажных образов в русской поэзии / М. Н. Эпштейн - М. : Высшая школа, 1990. - 306 с. 


\section{СПИСОК ВИКОРИСТАНИХ ДЖЕРЕЛ}

16. Percy Bysshe Shelley. Poems. - Electronic Resource. - Access mode : https://www. poemhunter.com/percy-bysshe-shelley/poems/.

\section{СПИСОК ВИКОРИСТАНОЇ ЛІТЕРАТУРИ}

1. Baker J. E. Shelley's Platonic answer to a platonic attack on poetry / J. E. Baker. - [Ed. by J. E. Baker]. - Iowa Univ. press, 1965. - 172 p.

2. Barcus J. E. Percy Bysshe Shelley: The Critical Heritage / J. E. Barcus. - Routledge, 1995. $-52 \mathrm{p}$.

3. Bloom H. Shelley's mythmaking / H. Bloom. - Ithaca-N.Y., 1969. - 278 p.

4. Duffy C. Shelley and the Revolutionary Sublime / C. Duffy. - Cambridge : Cambridge University Press, 2005. - 260 p.

5. Howe A. Shelley and Philosophy: On a Future State, Speculations on Metaphysics and Morals, On Life / A. Howe // The Oxford Handbook on Percy Bisshe Shelley [Ed. M. O’Neill, A. Howe]. - Oxford : Oxford University Press, 2013. - P. 101- 117.

6. Hugh R. Shelley and the chaos of history: a new politics of poetry / R. Hugh. - University Park : Pennsylvania State Univ., 1997. - 530 p.

7. O’Neill M. Introduction / M. O’Neill // The Oxford Handbook on Percy Bisshe Shelley [Ed. M. O’Neill, A. Howe]. - Oxford : Oxford University Press, 2013. - P.-115.

8. Woodman R. G. The apocalyptic vision in the poetry of Shelley / R. G. Woodman. - Toronto : Univ. of Toronto, 1966. - 209 p.

9. Vorobyova O. P. Obraz teksta v filologicheskich studiyakh: kognitivno-semioticheskiy aspekt / // O. P. Vorobyova // Problem predstavlieniya znaniy v yazykie. Tipy I format znaniya: Sb.nauch.tr. / RAN, In-t yazykoznaniya; MON RF; TGU im. Derzhavina : [pod. red. Kubriakovoy Y.S.]. - M.-Kaluga: Eydos, 2007. - P. 278-286.

10. Kaganovs'ka O. M. Tekstovi kontsepty khudozhnioyi prozy (na materiali frantsuz'koyi romanistyky XX storichch'a) / O. M. Kaganovs'ka. — K. : Vyd. tsentr KNLU, 2002. - 292 s.

11. Malenko O. Lingvo-estetychna interpretatsiya butt'a $v$ ukrains'kiy poetychniy movotvorchosti (vid fol'kloru do modernu) / O. Malenko. - Kharkiv : KHNPU, 2010. - 488 s.

12. Nieupokoyeva I. G. Revoliutsyonniy romantizm Shelli / I. G. Nieupokoyeva. - M. : Gosudarstvennoye izdatel'stvo khudozhestvennoy literatury, $1959-471 \mathrm{~s}$.

13. Riker P. Konflikt interpretatsiy (Ocherki o germenevtikie) / P. Riker. - M.: Progress, 1995. $-367 \mathrm{~s}$.

14. Stiepanov Y. S. Frantsuzkaya stilistika (v sravnenii s russkoy) / Y. S. Stiepanov. - M. : Editorial URRS, 2003. - 359 s.

15. Epshteyn M. N. Priroda, mir, taynik vselliennoy. Sistiema pieyzazhnych obrazov russkoy poezii / M. N. Epshteyn. - M.: Vysshaya shkola, 1990. - $306 \mathrm{~s}$.

\section{SOURCES}

16. Percy Bysshe Shelley. Poems. - Electronic Resource. - Access mode : https://www. poemhunter.com/percy-bysshe-shelley/poems/. 


\title{
ЗОБРАЖЕННЯ ПРИРОДНИХ І ПРОСТОРОВИХ КОНЦЕПТІВ У ПОЕЗІЇ ПЕРСІ БІШІ ШЕЛЛІ
}

\author{
Наталія Романишин \\ Національний університет “Львівська політехніка", \\ вул. С. Бандери, 12, м. Львів, Украӥна, 79000 \\ nataliya.romanyshyn@gmail.com
}

У статті розкрито особливості образного втілення просторових і природних художніх концептів у поетичному дискурсі Персі Біші Шеллі шляхом аналізу авторських індивідуальних стилістичних преференцій, типових частотних образних моделей, мотивів, композиційних структур. Визначено основні способи та принципи створення символічного та асоціативного паралелізму між природними елементами й різноманітними екзистенційними феноменами та поняттями. Отримані результати дають можливість визначити домінантні риси авторської поетики, типові метафоричні моделі, у яких назви природних стихій та явищ слугують джерелом і метою метафоризації, спектр їхніх символічних смислів. Реконструкція авторської художньо-концептуальної системи спирається на розуміння сутнісної специфіки поетичної мови, ії образно-символічного та лексико-семантичного потенціалу як основного засобу вербалізації художніх концептів, відображення їхніх когнітивних, естетичних та емоційно-експресивних аспектів.

Унікальність поетичного мислення Шеллі в аспекті підходів, які автор застосовує до поетичної актуалізації просторових та природних концептів, полягає у прагненні охопити та виявити у їхній символіці поняття та явища індивідуального та колективного буття. Основне місце у поетиці Шеллі посідають алегорії та композиційні метафори, що розгортаються на основі універсального символічного та асоціативного паралелізму між природою та людиною, природою та суспільством. У процесі поетичного моделювання досліджуваних художніх концептів ці засоби дають змогу розкрити фундаментальні екзистенційні принципи, складність взаємодії людської психіки, душі, творчості та когніції.

Методологічну основу дослідження становить розуміння текстового значення не як статичної, внутрішньої ознаки тексту, а як динамічного результату художньої комунікації, розкриття якого вимагає широкого спектра різноманітних дослідницьких методів і прийомів, вибору відповідного дослідницького вектора, гнучкості процедур та етапів аналізу. Дослідження індивідуальної поетичної системи передбачає поглиблений аналіз різноманітних проявів авторської інтелектуальної та креативної діяльності задля проникнення в особливості поетової концептуальної картини світу, системи цінностей і світоглядних пріоритетів.

Ключові слова: поезія, романтизм, Персі Біші Шеллі, художній концепт, художній дискурс. 